\title{
MORPHOLOGICAL STUDY OF THE TESTES OF THE DOVE COLUMBA LIVIA (GMELIN) (COLUMBIDAE, COLUMBIFORMES)
}

\author{
Sandra Maria das Graças Maruch ${ }^{1}$ \\ Maria Eloiza de Oliveira Teles ${ }^{1}$ \\ Maria das Graças Ribeiro ${ }^{1}$
}

\begin{abstract}
Known as "domestic dove", the Columba livia (Gmelin. 1789) is a columbidae species widely distributed in Brazil, whose reproductive biology has been studied by many researchers. The testes of 12 Columba livia males were collected and prepared for histologic examination under an optical microscope, the results of which were analysed and photographed. The tunica alhuginea that covers the testes consists of a thick, not very cellular layer of dense connective tissue. Groups of interstitial cells with typical morphological appearance and surrounded by loose, well vascularized connective tissue are observable within the organ. between the seminiferous tubules. The seminiferous tubules are thick, intensely wound and, when seen in cross section. show Sertoli cells and spermatogenic lineage cells in different stages of development. These include spermatogonia (type A. elear: type A. dark: and type B), spermatocytes I and II. spermatids, and a large number of spermatozoons. Similarities are found between the histological findings described and those reported for the testes of Columbina talpacoti (Temminck, 1811).

KEY WORDS. Columbidae, birds, genital apparatus, testis
\end{abstract}

The scarcity of data in the scientific literature concerning the reproduction of brazilian birds has caused, in general, that public organs use inappropriate methods and techniques in population control of bird species that constitute our avifauna. This position has represented a risk to several species and also, at times, to health of human beings who use them as a food source. The Columbidae are among the victims, since they are birds that are very well adapted and widely distributed in Brazil.

The rock dove Columba livia (Gmelin, 1789) is a species of Columbiformes of small size, quite well accepted and even domesticated by urban population. From the old world imigrated to the Americas, being found in almost all brazilian states and also in other countries like Bolivia, Chile and Peru.

The morphological study of Columbia livia testes presented here is a part of a wider project on reproductive biology and determination of gonadal maturation stages of Columbideos, aiming to provide data that may contribute to the control and preservation of brazilian avifauna.

Despite the existence of few data on the histology of Columbiformes, the

1) Laboratório de Histologia Animal. Departamento de Morfologia, Universidade Federal de Minas Gerais, Caixa Postal 2486, 31270-190 Belo Horizonte, Minas Gerais, Brasil. 
morphological pattern described for other birds species by BRADLEY (1950), BaILEY (1953), LAKE (1957), HOFFMAN \& VOLKER (1969), KING (1981), ORSI et al. (1984), MARUCH et al. (1991), among others, has offered support to this study.

\section{MATERIAL AND METHODS}

To enable the accomplishment of this study, 12 males of the dove Columba livia, caught in Belo Horizonte and neighborhood, in the state of Minas Gerais, were used. The animals were sacrificed through ether inhalation and submitted to a ventral, median and longitudinal incision in order to perform macro and mesoscopic studies of the gonadal apparatus and further testes dissection. Testes fragments were fixed in Bouin solution (LILLIE \& FULMER 1976) and Helly solution modified (HocherEAU 1963), included in paraffin and processed according to routine histological techniques: Hematoxylin-Eosin and Gomori's trichromic stainings, Weigert technique (modified by NOGUEIRA \& RIBEIRO 1980) to evidenciate elastic fibers and Gomori's technique (GOMORI 1952) to demonstrate reticular fibers. The results were analised, described and photographed using a photomicroscope Olympus.

\section{RESULTS}

Being placed symmetrically on each side of the corporal median line, Columba livia testes are in pair, inside the abdominal cavity, cranially related to the ventral surface of the kidney. In young males, the testes are covered by a slim layer of connective tissue, the albuginea, poor in cells, well vascularized, where are found interstitial cell groups that will be described later. The seminiferous tubules are narrow and show an irregular distribution when observed in transversal sections. The lumen is not very evident and the epithelium of the seminiferous tubules wall is basically constituted by sustaining cells, showing irregular and basal nuclei, forming an authentic layer close to basal membrane, alternated with a number of spermatogonia. The spermatogonia have big and clear nuclei, diffuse chromatin and evident nucleolus. A few spermatocytes I are observed, showing an irregular distribution. Spermatids and spermatozoon were not observed in the seminiferous tubules of young males.

The testes, in adults, are covered by dense and ordened connective tissue, forming the tunica albuginea, rich in collagen fibers and with few elastic and reticular fibers (Fig. 1). In the inner part of the organ, a well vascularized and loose connective tissue is found, constituting a sustaining tissue for the seminiferous tubules. In this tissue are observed fine collagen fibers, few elastic fibers and abundant reticular fibers, these accumulated in the seminiferous tubules wall (Fig. 6). Among the tubules are seen interstitial cells, presenting a poorly stained cytoplasm and characteristics of lipid secreting cells (Fig. 3).

The seminiferous tubules occupy the majority of the testicular area and form a ramified net (Fig. 3). Each tubule presents, externally to the basal membrane, a 

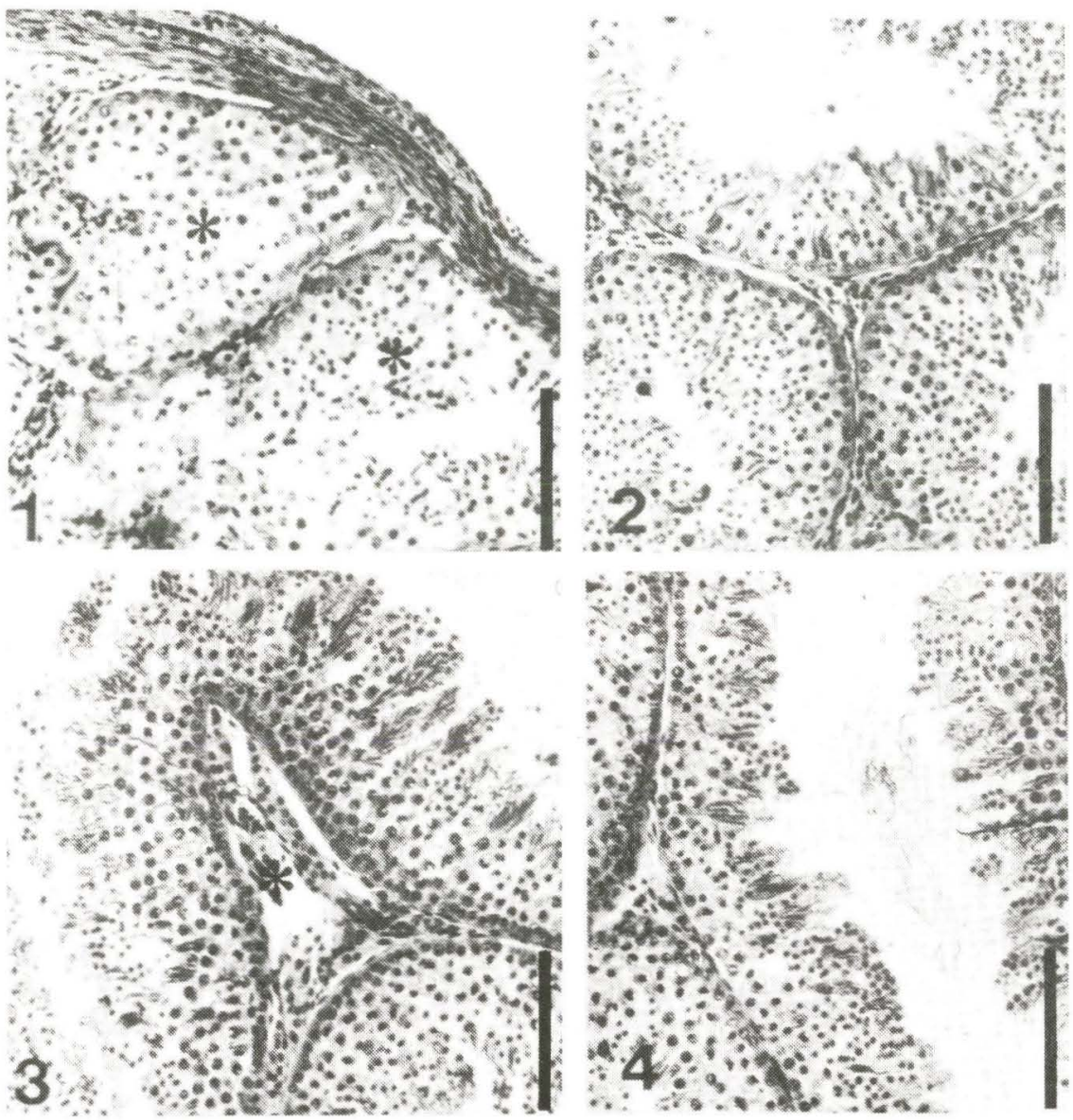

Figs 1-4. Sections of Columba livia testes. (1) Transversal section evidenciating the testis albuginea and seminiferous tubules $\left(^{*}\right)(\mathrm{HE}$, har $=0,5 \mu \mathrm{m}) ;(2)$ transversal section of seminiferous tubules showing the spermatogenic cells in different maturation stages ( $\mathrm{HE}$, bar $=0,25 \mu \mathrm{m})$; (3) transversal section evidenciating anastomosed seminiferous tubules and interstitial cells $\left(^{*}\right)$ (HE, bar $\left.=0.25 \mu \mathrm{m}\right)$; (4) Longitudinal section of seminiferous tubules evidenciating spermatogenic lineage cells in different maturation stages (bar) (HE, bar $=0.25 \mu \mathrm{m})$.

slim connective tissue, quite celular, where are seen, besides the connective cell nuclei, nuclei of mioid cells, elongated and showing a loose chromatin. In the seminiferous tubule wall, one can observe sustaining cells (Sertoli cells) and spermatogenic lineage cells, in different maturation stages (Figs 2-5). The Sertoli cells, that not present a quite evident cytoplasm in optical microscopy, showing a volumous and of irregular shape nucleus, frequently basally located, with diffuse chromatin and evident nucleolus.

Three types of spermatogonia were observed, among the spermatogenic cells: type A clear, type A dark and type B. The spermatogonium of type A clear 



Figs 5-6. (5) Longitudinal section of seminiferous tubules evidenciating spermatogenic lineage cells in different maturation stages (bar) $(\mathrm{HE}, \mathrm{bar}=0,25 \mu \mathrm{m})$ : (6) section of testes showing reticular fibers connective interstitial tissue surrounding the seminiferous tubules (bar $=0.5 \mu \mathrm{m})$.

corresponds to the commonest type found and shows a big, spherical and vesiculous nucleus, with loose chromatin and evidente nucleolus; type A dark presents a smaller nucleus, with a more condensed chromatin and type B presents a volumous nucleus, with loose chromatin, evident nucleolus and chromatin clots adhered internally to the nuclear involucre (Fig. 2). The primary spermatocytes, very numerous, are cells that present volumous nuclei that show various subphases of meiotic division and are irregularly disposed in the seminiferous tubule wall (Fig. 2). The secondary spermatocytes are smaller and are rarely seen.

The spermatids present small nuclei, spherical in the beginning, with loose chromatin and evident nucleolus and are placed near the seminiferous tubule lumen (Fig. 4). Several morphological changes are seen in the spermatids during spermiogenesis, as cytoplasm reduction, nucleus elongation, chromatin condensation and the acrosome appearing. The spermatozoons, disposed in clusters, are similar in aspect to those of the mammalians.

\section{DISCUSSION}

WORDEN (1956), GETTY (1981) and KING (1981) state that birds, in general, in their period of more intense sexual activity, present very volumous testes that are oval-shaped and of whitish color. Such a data, in a similar way, observed in Columbina talpacoti by MARUCH et al. (1991) and in Columba livia. Another data seen in this species is the smaller thickness of the tunica albuginea in young males, when it is compared to adult males, a data that is consistent with the description by GeHLAUT et al. (1985), in domestic cock and by MARUCH et al. (1991), in Columbina talpacoti. 
In Columba livia it was not observed the presence of connective tissue septa that come from tunica albuginea and divide the testis in lobules. Similar results were found by MARVAN (1969), LAKE (1971) and GEHLAUT et al. (1985) in domestic cock; Mercadante et al. (1983) in dove; HofFMAnN \& VOLKER (1969) in other species of domestic birds and MARUCH et al. (1991) in the small dove Columbina talpacoti.

In the seminiferous tubules of Columba livia one can observe a slim connective tissue, rich in blood vessels, showing interstitial cell groups that present morphological characteristics of steroid secretory cells. Such a results confirm the descriptions by BRAdley (1950), Hoffmann \& Volker (1969), GeTTy (1981), KING (1981) and MARUCH et al. (1991), in different bird species.

In the seminiferous epithelium of dove, domestic cock and other bird species, one can see spermatogenic lineage cells in different maturation stages (LAKE 1957; KING 1981; ORSI et al. 1984, and MARUCH et al. 1991). Such a morphological aspects were also observed in the seminiferous epithelium of Columba livia.

For BRADLEY (1950), in domestic cock, the spermatogenic cells from spermatogonia to spermatozoon, are disposed in layers, in a regular sequence, from the basal membrane up to the seminiferous tubule lumen. In Columba livia, the organization observed is similar to that described in Columbina talpacoti by MARUCH et al. (1991). Although there is a certain organization in the germinative cell distribution, one can not notice the regularity (or synchronicity) described by BRADLEY (1950).

ACKNOWLEDGMENTS. The authors thank for the financial sponsoring from Pró-Reitoria de Pesquisa da Universidade Federal de Minas Gerais and from Fundação de Amparo à Pesquisa do Estado de Minas Gerais (FAPEMIG) and also for the valuable collaboration of the translator Maria da Glória A. Ferreira, of the photographic laboratory technician Ivone do Carmo de Oliveira, of the librarian Maria Cecília de Souza Lima and of the biologist Sandra Resende Lima, in charge of the preparation of the material used in this study.

\section{REFERENCES}

BAILEY, R.E. 1953. Accessory reproductive organs of male fringillid birds: seasonal variations and response to various sex hormones. Ant. Rec. 115: $1-20$.

BRADlEY, O.C. 1950. The reproductive organs, p. 57-70. In: O.C. BRADLEY (ED.). The structure of the fowl. London, J.B. Lippincott Company, 185p.

Gehlaut, B.S; M.R. Malik; A.M. Shrivastava \& I.C. Datta. 1985. Comparative histomorphochemical studies on the testes of dwarf (dw) and non-dwarf fowl (Gallus domesticus). Ind. J. Anim. Sci. 55: 870-72.

GetTy, R. 1981. Anatomia dos animais domésticos. Rio de Janeiro, Interamericana, $1962 p$.

GOMORI, G. 1952. Microscopic histochemistry principles and practice. Chi- 
cago, University of Chicago Press, 277p.

HocherEaU, M.T. 1963. Étude comparée de la vague spermatogétique chez le taureau et chez le rat. Ann. Biol. Anim. Biochim. Biophys. 3: 5-20.

Hoffmann, G. \& H. Volker. 1969. Anatomia Y fisiologia de las aves domesticas. Zaragoza, Acribia, 189p.

HUBER, A. 1916. A note on the morphology of the seminiferous tubules of birds. Anat. Rec. 2: 177-180.

KING, A.S. 1981. Aparelho urogenital das aves; órgãos genitais masculinos, p. 1805-1813. In: R. GetTy (ed.). Anatomia dos animais domésticos. Rio de Janeiro, Interamericana, 743p.

LAKE, P.E. 1957. The male reproductive tract of the fowl. J. Anat. 91: 16-129. 1971. The male in reproduction, p.1411-1447. In: D.J. BELL \& B.M. Freman (ed.). Physiology and biochemistry of the domestic fowl. London, Academic Press., vol. 3, 535p.

Lillie, R.D. \& H.M. Fulmer. 1976. Histopathologic technic and practical histochemistry. New York, Mc Graw-Hill, 942p.

Maruch, S.M.G.; M.E.O. Teles \& M.G. Ribeiro.1991. Estudo morfológico do testículo de Columbina talpacoti (Temminck, 1811). Columbidae - Columbiforme. Rev. Bras. Cienc. Morfol. 8: 72-76.

Marvan, F. 1969. Postnatal development of the male genital tract of the Gallus domesticus. Anat. Anz. 124: 443-462.

Mercadante, M.C.S.; A.M. Orsi; C.A. Vicentini; M.M. Valente \& S.M. DIAS. 1983. Anatomical observations on the male reproductive system of the pigeon (Columba livia). Rev. Cienc. Biomed. 4: 37-44.

NogueIRA, J.C. \& R.D. Ribeiro. 1980. A simplified Weigert's method for staining elastic fibers. Arq. Esc. Vet. Univ. Fed. Minas Gerais 32: 333-335.

Orsi, A.M.; M.C.S. Mercadante; E. Dias \& C.A. Vicentini. 1984. Some observations on the morphology of the pigeon's seminiferous epithelium cells. Anat. Histol. Embryol. 13: 327-332.

WORdEN, A.N. 1956. Reproductive system, p.48-54. In: A.N. WORDEN (ed.). Functional anatomy of birds (Cage Birds). London, Academic Press, 136p.

Recebido em 19.VII.1994; aceito em 08.III.1995. 